The original publication is available at http://www.springerlink.com

\title{
Assessment of polycyclic aromatic hydrocarbon concentrations in mussels (Mytilus galloprovincialis) from the Western basin of the Mediterranean Sea
}

Francois Galgani ${ }^{\mathrm{a},{ }^{*}}$. Conception Martínez-Gómez ${ }^{\mathrm{b}} \cdot$ Franco Giovanardi ${ }^{\mathrm{c}} \cdot$ Giulia Romanelli ${ }^{\mathrm{c}} \cdot$ Josep Caixach $^{\mathrm{d}}$. Alessandro Cento $^{\mathrm{e}}$. Alfonso Scarpato ${ }^{\mathrm{c}} \cdot$ Samir BenBrahim $^{\dagger} \cdot$ Sabri Messaoudi $^{\mathrm{g}} \cdot$ Salud $^{\mathrm{C}}$ Deudero $^{h} \cdot$ Mostafa Boulahdid $^{i} \cdot$ José Benedicto $^{b} \cdot$ Bruno Andral $^{a}$

\footnotetext{
${ }^{\text {a }}$ Laboratoire LER/PAC, IFREMER, ZP Bregaillon, BP n॰ 330, 83507 La Seyne/Mer, France

${ }^{\mathrm{b}}$ Instituto Español de Oceanografía (IEO), Varadero 1, 30740 San Pedro del Pinatar (Murcia), Spain

${ }^{c}$ ISPRA, Via di Casalotti 300, 00166 Rome, Italy

${ }^{d}$ CSIC -ACA, Jordi Girona 18-26, 08034 Barcelona, Spain

e PSTS S.c.p.a., Zona Industriale Blocco Palma 1, S G. Agnelli Angolo, 95030 Catania, Sicily, Italy

${ }^{\mathrm{f}} \mathrm{INRH}$, rue de Tiznit, Casablanca 01, Morocco

${ }^{9}$ INSTM, 28 rue du 02 mars 1934, 2025 Salammbo, Tunisia

${ }^{\mathrm{h}}$ Univ Is Baleares/IMEDEA, Cra. de Valldemossa Km 7,5. Palma, 07122 Balearic Islands, Spain

'ESSMAL, bois des cars, BP 19, 16320, Alger, Algeria
}

* Corresponding author : F. Galgani, email address : francois.galgani@iffemer.fr

\begin{abstract}
:
The Mytilos project was carried during the last 3 years (2004-2006) in order to evaluate the level of chemical contamination along the coasts of the western basin of the Mediterranean Sea. Active mussel watch consisted of caged (12 weeks) Mytilus galloprovincialis at 123 stations along the Mediterranean coasts of Spain, France, Italy, North Tunisia, Algeria and Morocco. Results indicated total PAHs levels in the range $22-106 \mu \mathrm{g} / \mathrm{kg}$ dry weight. All large towns or industrial areas from all countries of the basin were affected. Analysis of the origin of contamination demonstrated mainly a pyrolytic origin except in some areas such as Maddalena, Napoli, Alger, and Cornigliano (Genova). Statistical analysis of the PAHs accumulation data enabled the characterisation and ranking of each coastal area. The overall results give scientific and technical basis for large-scale monitoring of the $\mathrm{PAH}$ contamination in the entire western Mediterranean basin.
\end{abstract}

Keywords: PAHs - Mediterranean Sea - Mytilus galloprovincialis - Caging - Monitoring 


\section{Introduction}

Among the range of organic contaminants entering coastal areas of the Mediterranean sea, polycyclic aromatic hydrocarbons (PAHs) raise special concern due to their persistence in the environment and their mutagenic and carcinogenic potential. PAHs like naphthalene, benzo[a]anthracene, benzo[b]fluoranthene, benzo[k]fluoranthene, benzo[a]pyrene and dibenzo[a,h]anthracene have been defined by the International Agency for Research on Cancer (IARC) as possible or probable human carcinogens (groups 2A and 2B) (IARC, 1989) that may pose risk to humans and marine organisms (Berthou et al., 1987; Varanasi et al., 1987; Vethaak et al., 1996) and specially during embryogenesis and early stages of development (Geffard et al., 2002; Incardona et al., 2005). Once the hydrocarbons are in the organism, there is a wide variation in the types and magnitudes of physiological responses such as biodegradation, bioaccumulation and biotransformation. Such processes finally determine the bioavailibility and toxic potency of PAHs and other petroleum-related compounds in the marine enviroment. PAHs are derived mainly from anthropogenic sources, though some of them may also be of biogenic origin. They enter in the aquatic environment primarily from petroleum sources and the long-range transport on particulates, following incomplete combustion of organic matter (Neff, 2002).

The Mediterranean coast is of special concern due to the reduced circulation, absence of tides, the importance of oil traffic routes and the amounts of industrial inputs. This is the case of the North West basin with areas described as contaminated by oil as demonstrated measuring the contamination of sediments (Benlahcem et al., 2002; De Luca et al., 2004; Romano et al, 2004; Trabelsi and Driss,2005; Mille et al., 2007 ), in water (Lipiatou et al, 1997; Bouloubassi et al., 2006) in marine organisms (Baumard et al., 1998, 1999; Villeneuve et al. 1999; Piccardo et al., 2001; Andral et al., 2004) and measuring biological effects (Galgani et al., 1992; Burgeot et al., 1993, 1995; Porte et al., 2000; Romeo et al, 2003; Minier et al, 2006; Box et al , 2007; Martínez-Gómez et al., 2008) .

Investigations targeting the use of natural mussels to biomonitor oil contamination in the marine environment is of common use since they accumulate contaminants from the surrounding seawater and are resistant to a wide range of contaminant concentration. The use of the mussel, chiefly of the genus Mytilus, to study levels and trends of chemical contamination in coastal waters was first suggested in the mid-1970s (Goldberg, 1975). Biomonitoring using mussels is based on their ability to accumulate chemical contaminants in its tissues to a degree proportional to their bioavailability. Marine organisms like filter feeder molluscs have a huge ability to accumulate hydrocarbons because they have not got an efficient system to metabolize them, though some specific metabolic markers have been described for PAH (Michel et al., 1994; Burgeot et al., 2001). Because the bioaccumulation phenomenon covers a period lasting several months, the problem of daily fluctuation of water masses is eliminated, and the higher levels of contaminants retained by the organisms can more easily be measured. The mussel Mytilus galloprovincialis, which is abundant along extensive areas of the Mediterranean coasts, has all the desirable characteristics of a biomonitor and is the main species recommended to perform biomonitoring activities in MED POL programmes (UNEP/FAO/IOC/IAEA, 1993; UNEP, RAMOGE, 1999). In addition, both the biology and ecology of the species are documented.

The identification and quantification of contaminants in biota within monitoring programmes should ideally allow the comparison among sites/areas. Two different strategies have been adopted including the use of indigenous populations of wild or cultivated mussels (passive biomonitoring) (Goldberg, 1975; Claisse, 1989) or transplanting individuals from a reference site (active bio monitoring) (Kock and Kramer, 1983; Gunther et al., 1996). The musseltransplantation technique was used to solve the problem of scarce natural mussel stocks in much of the coastal zone, and transplanted mussels can be immersed at any location and/or 
depth. The transplantation method also enables the control of some confounding factors such as the source, age, and stage of sexual maturity of the samples. However, implementing it on a large geographic scale introduces factors such as variations in physiochemical characteristics and food availability in the immersion zones. Although the concentrations measured in the tissue are a function of bioavailable pollutant levels, for some contaminants, the bioaccumulation factor depends on mussel growth in relation to the primary food production, or trophic capacity of the environment (Nolan and Dahlgaard, 1991) or lipid content (Capuzzo et al., 1989). For PAHs, these interferences are not important (Andral et al., 2004; Casas, 2007) enabling the comparison within sites. Moreover, in our experiment, sampling was performed during non spawning period to avoid any interference with lipid metabolism during the maturation of gonads.

Within the context of the MYTILOS project, an assessment of PAH content in caged mussels was performed along the shore line of the Western basin of the Mediterranean sea, including the coasts of Tunisia, Algeria, Morocco, Spain, France and Italy where mussels were caged in 123 different stations. The purpose of this pilot study was to implement a monitoring network making it possible to evaluate chemical contamination levels at a large scale level in the wastewater dilution zone of geographical reference sub - units. We describe results from this large scale pilot monitoring project. It should be a chance to relate the strategy of use caging mussels with the EU Marine Strategy, as a relatively easy tool to make and assessment of the chemical water quality of the different body waters among regions.

\section{Materials and methods}

\section{Field experiments}

Experiments were performed during 8 cruises (R/V L Europe and R/V Tethys) between 2004 and 2006 covering each year a part of the basin. The shoreline between Barcelona and Isola d Elba (Northern sub-basin) was investigated in 2004 whereas islands (Balearic, Sardinia, Sicilia) and central sub-basin were investigated in 2005. The 2006 cruise was concerning the coasts from Alboran sea and North Africa, including a reference station in the TunisiaSicilia canal, offshore the island of Pantelleria.

The mussels came from a aquaculture farm in Languedoc-Roussillon which harvests contamination-free mussels from the open sea. Batches were made up of adult 18-24 months old mussels of standardized shell size $(50 \pm 5 \mathrm{~mm})$, sorted twice according to the height of the shell through $19-\mathrm{mm}$ mesh. The $3-\mathrm{kg}$ samples were stored in polyethylene bags mounted on PVC tubing and re-immersed for ten days so they can re-cluster prior to transplantation. The 123 man-made MYTILOS biointegrator network stations were immersed between April and May and hauled out after 3 months (Figure 1). The immersion process was carried out during the mussels sexual dormancy period (spring). At this time, reserves of accumulated energy improve immersion conditions and minimize tissue-growth variations from site to site. The choice of this season was also a means of minimizing the effect of biofouling on the security of the moorings.

The stations were immersed between $20 \mathrm{~m}$ (sandy littoral) and $40 \mathrm{~m}$ (rocky littoral). Usually, an 11-I buoy attached to the upper part of the mussel bag maintained it at a depth of 6 - 8 meters from the surface, regardless of any condition of biofouling or muddiness. The system was anchored to the bottom by means of ballast weighing about $30 \mathrm{~kg}$, connected to the bag by a 7-mm polypropylene line. Moorings were doubled or tripled in zones exposed to trawling. At haul-out time, sampling stations were located by means of combined use of 
DGPS, panoramic sonar, and depth sounding systems. Samples were recovered either by divers or by grapping hooks.

During recovery on site, the mussels were separated and rinsed in seawater. Mortality and several biometric parameters linked to growth were recorded: length, width and height of the shell.

\section{Chemical analysis}

At each station, the samples were pre-processed according to standardized procedures (Andral et al., 2004). The mussels were opened raw and the flesh was scraped out of the shell with a stainless steel scalpel. Dissected whole soft tissues, from 30-40 individuals were pooled into a composed samples and then lyophilized. Shells were dried at $60{ }^{\circ} \mathrm{C}$ in the oven for $48 \mathrm{~h}$ and then weighed. Flesh was weighed after freeze-drying. The ratio of dry flesh weight to dry shell weight (FW/ SW) was used to determine a condition index (CI) for each sample. During the period of sexual dormancy, this quotient is a good indicator of mollusc growth. PAHs were separated and quantificated by means of High Performance Liquid Chromatography (HPLC) using methanol-water gradient as mobile phase and a mass spectrometry detection (HPLC-MS). The following sixteen hydrocarbons analyzed were: naphtalene, acenaphthene, acenaphtylene, fluorene, phenanthrene, anthracene, fluoranthene, pyrene, benzo[a]anthracene, chrysene, benzo [b]fluoranthene, benzo[k]fluoranthene, benzo[a]pyrene, benzo[g,h,i]perylene, dibenzo[a,h]anthracene and indeno[1,2,3-c,d]pyrene. The results of PAHs are expressed as $\mu \mathrm{g} \mathrm{kg-1} \mathrm{d.w.} \mathrm{and} \mathrm{they} \mathrm{are}$ referred as the sum of the total individual PAHs analysed ( $\Sigma 16 \mathrm{PAHs})$. Analyses were performed under the Quasimeme assurance quality program. In the analysis of the data, only the PAH values $\geq$ the analytical detection limit were considered (i.e. $\geq 1 \mu \mathrm{g} / \mathrm{Kg}$ ). All results are referred to concentration in dry weight tissue (d.w.).

\section{Statistical tools and methods.}

The sample data processing was performed by using the $R$ (V. 2.11) software. In the analysis of the sample distributions, the translation method of Johnson (1949), has been applied. In order to fit frequency curves, we have largely utilised R package SuppDist (Wheeler, 2005. SuppDists: Supplementary distributions. R package version 1.0-13. http://www.bobwheeler.com/stat.), that allows to compute density function [dJohnson()], distribution function [pJohnson()] and its inverse [qJohnson()]. The summary function [sJohnson()] provides a list of the whole statistical parameters of the distributions. The calculation algorithms for the estimate of the Johnson parameters are those of Wheeler (1980: quantiles method), and Hill et al. (1976: moments method). More details about the application of Johnson method to the case of water quality parameters characterising coastal environment, are reported in Giovanardi et al. (2006)

Cartography of results was performed using the Karto software (IFREMER)

\section{Results}

PAHs were analysed in caged mussels from 123 sites using the same methodology by the same laboratory. The general distribution of $\Sigma 16 \mathrm{PAH}$, as given in figure 1 , demonstrate the homogeneity of results and the occurrence of high levels in areas of Marseille (105.5 $\mu \mathrm{g}$ per $\mathrm{kg}$ ), the gulf of Genova, Isola Giannutri, Maddalena, Torpaterno and Napoli (respectively $70.5,78.5,61.1,69.9$ and $80.4 \mu \mathrm{g}$ per $\mathrm{kg}$ ) , Soller (87.7 and $99.9 \mu \mathrm{g}$ per $\mathrm{kg}$ ), Nador $(75.8 \mu \mathrm{g}$ 
per $\mathrm{kg}$ ) Alger (72.5 $\mu \mathrm{g}$ per $\mathrm{kg}$ ) and Tunis (68. 6 and $69.7 \mu \mathrm{g}$ per $\mathrm{kg}$ for two stations). On the opposite, lowest values were measured in Galeria and Capo de Creus $(21.9 \mu \mathrm{g}$ per $\mathrm{kg}$ each), in Javea (Spain, $22 \mu \mathrm{g}$ per $\mathrm{kg}$ ), in Oued Zhor and Oran, Algeria (25 $\mu \mathrm{g}$ per kg each) and Lavezzi islands (25.4 $\mu \mathrm{g}$ per $\mathrm{kg}$ ). As I told you I think this is a bit hard to read, but I have already comment that.

There were no significant differences $(P<0.05)$ within countries (Table 1$)$. However, Except in Alger(72.5 $\mathrm{\mu g}$ per $\mathrm{kg}$ ) levels of hydrocarbons were found very low in Algeria.

The specific PAH phenanthrene, anthracene. Dibenzo[a,h]anthracene, acenaphtylene, benzo[a]anthracène, benzo[b]fluoranthène, benzo[k]fluoranthene, indene $[1,2,3-$ cd]pyrène and indene[1,2,3-c,d])pyrene were under the detection limits in most of the stations or at very low levels, the only exceptions being benzo[a]anthracene in Ibizza $(4.3 \mu \mathrm{g}$ per $\mathrm{kg}$ at San Antonio), in 2 stations from the bay of Tunis (8 and $9.2 \mu \mathrm{g}$ per $\mathrm{kg}$ ). Indene(1,2, c,d]pyrene was also high in Torpaterno $(6.2 \mu \mathrm{g}$ per $\mathrm{kg})$.

Others PAHs were largely above detection limits and only PAHs which were significantly detected were mapped (figure 2). Acenaphtene was heterogenously distributed with higher values in northern part of the basin. Levels up to 14 (Ebro), 11 - 25 (From Montpellier to Marseille) and 8.2 - 8.9 (Imperia- Cornigliano) $\mu \mathrm{g}$ per $\mathrm{kg}$ were measured whereas the maximum values in North Africa was $2.7 \mu \mathrm{g}$ per $\mathrm{kg}$ (Alger) with only 3 stations with values above detection limits (0.5). Anthracene was not detected in $96(79 \%)$ of the stations and was elevated only at Alger ( $5 \mu \mathrm{g}$ per $\mathrm{kg})$, Montaldo di Castro $(4.6 \mu \mathrm{g}$ per $\mathrm{kg})$ and, on a lesser extent, around Nice (3.3 $\mu \mathrm{g}$ per kg). Benzo[a]pyrene was up to 7.6 (Alger), 9 (Palermo), 7.7 (Ibizza), 11 (isola Giannutri), 7.9 (Frejus) and 9 (Medes islands) and undetected in $25 \%$ of the stations.

Chrysene and fluoranthene were distributed with the same pattern. For chrysene, the highest values were found in Ibizza $(7.1 \mu \mathrm{g}$ per $\mathrm{kg})$, Zinola $(6.5 \mu \mathrm{g}$ per $\mathrm{kg})$, Napoli $(7.3 \mu \mathrm{g}$ per $\mathrm{kg}$ ) and the bay of Tunis (9.7 and $7.3 \mu \mathrm{g}$ per $\mathrm{kg})$. The levels of fluoranthene were also higher in Ibizza (San Antonio, $11.0 \mathrm{ug}$ per kg), Cornigliano $(7.5 \mu \mathrm{g}$ per kg), Napoli $(16.0 \mu \mathrm{g}$ per $\mathrm{kg}$ ) and Tunis bay (11.0 and $10.1 \mu \mathrm{g}$ per $\mathrm{kg}$ ). Respectively 67 (55\% ) and 17 stations were found without any detectable chrysene and phenanthrene.

High concentrations of fluorene were found in Ibizza (Soller, $41.0 \mu \mathrm{g}$ per $\mathrm{kg}$ ), Maddalena and Tavolara (10.4 and $10.6 \mu \mathrm{g}$ per $\mathrm{kg}$ ) and Milazzo and Termini (11.0 and $12.0 \mu \mathrm{g}$ per $\mathrm{kg}$ ). The six stations comprising Javea, Cap Creus, Porto Torres, Palmarola, Gaeta and Tunis bay were under the detection limits $(0.5 \mu \mathrm{g}$ per $\mathrm{kg})$. For naphthalene, the highest values were obtained in Marseille (37 $\mu \mathrm{g}$ per kg),Soller (29), Tavolara and Porto Torres (20.7 and $32.0 \mu \mathrm{g}$ per kg), Nador (42.0 $\mu \mathrm{g}$ per kg), Gaeta, Torpaterno and Montalto (23.0, 25.0 and $31.0 \mu \mathrm{g}$ per $\mathrm{kg})$. Phenanthrene was high at Maddalena, Piombino and Giannutri (10.4, 7.3 and 7.4 $\mu \mathrm{g}$ per kg), Ibizza (San Antonio, $9.9 \mu \mathrm{g}$ per $\mathrm{kg}$ ) and La Galite and Tunis bay (10.3 and $8.8 \mu \mathrm{g}$ per $\mathrm{kg}$ ). On the other hand, lowest concentrations of phenantrene were found in Javea (1.6 $\mu \mathrm{g}$ per kg ), Cap Creus (1.4 $\mu \mathrm{g}$ per kg), Montalto (1.6 $\mu \mathrm{g}$ per kg) and Oran (1.5 $\mu \mathrm{g}$ per kg).

Finally, pyrene was found at high concentrations in Cornigliano(16.0 $\mu \mathrm{g}$ per $\mathrm{kg}$ ), Soller (8.4 $\mu \mathrm{g}$ per $\mathrm{kg}$ ), Napoli $(10 \mu \mathrm{g}$ per $\mathrm{kg}$ ) and the bay of Tunis $(9.5 \mu \mathrm{g}$ per $\mathrm{kg}$ ), whereas concentrations of this compound were under the detection limits.in 36 stations (representing $29.5 \%$ of the sampling stations).

On the basis of the different ratios indices, a classification of the stations according to hydrocarbon origins was attempted. The caged mussels were compared to evaluate the sources of pollution. The molecular ratios (Figure 3) were calculated to precise the pyrolytic or petrogenic processes generating PAH (Soclo, 1986; Parlanti, 1990; Baumard et al, 1998b; Norena-Baroso et al, 1999; Picardo et al, 2001). Fluoanthene/Pyrene (Fl/Pyr; 
Petrogenic $<1>$ Pyrolytic), Phenanthere/Anthracene (Phe/An; Pyrolytic $<10-15>$ petrogenic ) and Chrysene / Benzo[a]anthracene (Chry/ BaA, ) were calculated. For stations with high levels of $\mathrm{PAH}$, lowest values of $\mathrm{Fl} / \mathrm{Pyr}$ (petrogenic sources) were found in Cornigliano (0.5) and Algiers 2 (0. 8) and highest values (pyrolytic sources) in Nador, Morocco (3.2), Porto Torres, Sardinia (3.0), in Skikda, Algeria (2.8), in the Rhone river (2.6), in Frontignan, France (2.2) and in the location of the wreck «Haven» in the gulf of Genova, Italy (2.2). In Corsica, were PAH were low, except Ajaccio (0.6) and in a lesser extent Portovecchio (1.0), the Fl/Pyr ratio was caractheristics from pyrolytic sources with values above 3 (Pino, Propriano, Bastia and Tavignanu) .

The origin of $\mathrm{PAH}$ was also estimated using Phe/An ratio. For stations with high hydrocarbons levels, even with values under 25 , this ratio was high (petrogenic sources ) in Madalena, Sardinia(20.80), Formentera , Balearic islands(16.6) and in a lesser extent at Torpatermo, Napoli and Bagnoli ( $14.60 ; 14 \& 13.60)$, but very low (Pyrolytic sources ) in Montalto di castro, Italy 0.76), Algiers 1(1) Barcelona, Spain (1,21), Nice, France (1.76).

$39 \%$ of stations exhibited values of the ratio Chry/BaA (Chrysene / Benzo - a anthracene) above 1.0 indicating the presence of petrogenic $\mathrm{PAH}$. The highest values were found at Porto ferraio, isola d Elba (9.8), Maddalena, Sardinia(8. 0) and at the mouth of the Ebre river (7.00) whereas lowest values (pyrogenic sources) were calculated at Bejaia, Algeria (0.33), Trapani in Sicilia (0.42), Algegiras, South Spain (0.45) and in the bay of Tunis $(0.45)$

Johnson's transformations applied to original data allowed computing a wide variety of nonnormal distributions, including distributions which are bounded on either one or both sides. Each of the raw PAHs sample frequency distributions were approximated to an appropriate type of probability distribution, as shown in Figure. 4 , where the general scheme of frequency curve classification is reported.

The reference system for distribution types is build up in the $\left(\beta_{1}, \beta_{2}\right)$ plan, where $\beta_{1}$ is skewness to the square and $\beta_{2}$ is kurtosis +3 . Log-normal system is defined by the points lying on the SL line. This line divides the plan in two more general systems of curves, one with variation ranges bounded at both extremities (System Bounded: SB), the other instead unbounded at either extremity (System Unbounded: SU). The SB system covers the region between the log-normal line and the straight line where it is worth the relationship $\beta_{2} \beta_{1}=0$. Beyond this line the impossible area extents, where the combinations requested between $\beta_{1}$ and $\beta_{2}$ for distributions identifying, will never happen. The remaining part of the $\left(\beta_{1}, \beta_{2}\right)$ plan, below the SL line, is covered by the SU system.

By inspecting the diagrams in Fig. 4, we can observe that the prevailing type of frequency distributions for several PAH species is the log-normal system. Resulting distributions for benzo[k]fluoranthene, pyrene, chrysene and so on, are strictly of (or very close to) lognormal type. Distributions related to other PAH species, like naphthalene, fluorene, acenaphtene, benzo(a)pyrene, are instead clearly belonging to the SB system. These different statistical behaviours probably reflect specific chemical properties of these substances and/or different pathways of contamination and accumulation in the mussels. This differentiation is worthy of deepening and studying and surely needs appropriate attention in future monitoring campaigns and researches.

By means of the above procedures, used for calculations and the successive graphical representation as shown in Figure. 5, the contamination level in the Western Mediterranean basin is now "certified" in terms of probability density functions (p.d.f.s) and associated concentration range of variation, for each of the PAHs taken into consideration.

\section{Discussion}

In our work, PAHs were measured in mussels caged at 123 stations along the dilution zone of the North West Mediterranean sea. Polycyclic aromatic hydrocarbons (PAH) derive mainly from anthropogenic sources and are widely distributed in the environment, particularly 
around industrial and urban centres. Accumulation in sediments is often used to assess contamination. However, transplanting molluscs from a reference site to a polluted area can be a feasible strategy for bio-monitoring the effects of environmental changes in coastal or estuarine zones (Romeo et al., 2003, Andral et al., 2004). In our study, total PAHs levels were ranging from 20.0 to $105.5 \mu \mathrm{g}$ per $\mathrm{kg}$ dry weight. The highest values were found around areas known for their contamination, including the large towns but also some industrial areas. The hot spots for pollution in the North western basin has been described since a long time (UNEP/Medpol, 1999 ;) and our results confirm in many case the situation, notably for Marseille, the Genova area, Napoli, Palermo, Tunis, Alger and Nador. The references sites, also were in many cases exempt of any PAHs contamination. Surprisingly, Some areas were found with PAH contamination as low as in reference sites. This is the case With Oran ( Algeria), one of the less contaminated site, even with a station located a the entrance of the Harbour, in front of an effluent output. This is also the case of Barcelona, the largest town of the basin with PAHs levels in the average range. On the counterpart, some reference sites, such as Isola Giannutri were shown with some high individuals PAH contents, probably linked with the adjacent source of aerial contamination of Piombino, as shown with the nature of individual PAH that are common to both site.

North Sardinia is of special interest with three areas of contamination including Maddalena, Porto Torres and Tavolara affected by low molecular weights PAHs. Maddalena was sampled in front of the San stefano military area while Porto Torres was sampled in front of the industrial harbor including an oil refinery. Beside, even lower, contamination of Tavolara was related to the vicinity of the adjacent Olbia Harbor where large amounts of some individuals low molecular weight PAH such as fluorene and naphtalene are occurring as demonstrated previously in native mussels (De Luca et al., 2005). In the same way, high levels of chrysene, fluoranthene and pyrene (tetra-aromatics) found in both caged and native mussels from Cornigliano, as a consequence of an industrial area characterized by the presence of a steel smelter and a coke oven (Piccardo et al., 2001) were confirmed in our experiment. The same type of contamination was also demonstrated in the bay of Tunis suggesting similar individuals PAHs patterns, and similar industrial processes, in local sources of PAHs. Benzo a pyrene and naphtalene were not regional but linked to industrial activity .

If the total PAH content is generally greater in native mussels (ref from PAHs concentrations in resident mussels from West Mediterranean sites here) than in caged animals, the different locations, at depth of some meters for caged animals, at the interface between water and air may explain this difference (Piccardo, 2001). Moreover, the mussel-transplantation technique enables the comparison of sites where natural mussels stocks are scarce. Then, transplanted mussels can be immersed at any depth down to 1500m (Galgani et al., 2004), which is very important in the Mediterranean sea where deep seas are occurring very close to the rocky shores. In addition, the differences observed in the accumulation of PAH by mussels and by SPMDs indicate that mussels also better reflect the total exposure than do SPMDs (Boehm et al., 2005) and more accurately reflect the pathways for PAH uptake and transfer from sediments into the food web. This correspond to the integration of pollution occurring during the immersion period. Finally, the transplantation method also enables the control of the source, age, and stage of sexual maturity of the samples. However, implementing it on a large geographic scale introduces factors such as variations in physiochemical characteristics and food availability in the immersion zones. It has been demonstrated that PAHs are the contaminants the less affected by trophic conditions (Andral et al. 2004; Boehm et al., 2005; Casas , 2007).

Generally, individuals PAHs concentrations enable to precise the source and nature of pollution. In some areas, such a Napoli were many industrials sources exists (Celico et al., 2001; Romano et al., 2004,) and Montalto di Castro with adjacent powerplant and/or transports from oil platform located in the south, most individuals PAHs were present at significative levels whereas most areas were demonstrated to be affected by just, one , two or three different individuals, mainly of low molecular weights (Naphtalene, acenaphthene, 
acenaphtylene, fluorene). In these case, contamination can be linked to one type of pollution and this should be confirmed by analyses. Finally, because of their diversity and because they were mixed, the identification of sources was more complicated in some large industrial areas such as Napoli, Alger or Palermo .

Mussels can directly absorb molecular low weight PAHs, while heavier molecular weight hydrocarbons are mainly ingested through the digestive system. Phenanthrene and pyrene are estimated to be absorbed at $88 \%$ and $74 \%$ respectively when the less soluble BaP is estimated to be absorbed through particle ingestion (Baumard et al., 1998; Piccardo, 2001). Therefore, besides the variability of sources, the strong difference in pattern of PAHs within sites could be explained by the turbidity, the presence of organic matter (rivers) but also by the differences of decontamination kinetics for each individual PAH (Rantamaki, 1997; Casas, 2007).

Sources of polycyclic aromatic hydrocarbons (PAHs) are multiple in the environment and have been discussed in detail previously (Baumard et al., 1999, Piccardo et al. 2001, Mille et al., 2007). They may be derived from direct deposition of petroleum, Natural or anthropogenic atmospheric deposition and early diagenesis of natural products in recent sediments. For these main sources, $\mathrm{PAH}$ compositional patterns are quite different. Quantitative measurements of various ratios applied in this study pointed to the possible sources of polycyclic aromatic hydrocarbons in many of the sampling stations. However, this statement must be done cautiously and still remains approximate, depending on metabolisation of individuals PAH that are affected by species, trophic states, turbidity etc. In the Mediterranean sea, the sources of polycyclic aromatic hydrocarbons are numerous and of various sources, and could explain the difficulties to determine the exact origin of the PAHs detected in the mussels. Pyrolytic origin has been identified as the main source of these compounds in Mediterranean coastal sediments (Benlahcen, 1997). Analysis of ratios determine however the petrogenic origin of PAHs in italians sites such as Maddalena, Palermo, Napoli area, Cornigliano and in lesser extent in Alger. Ballasting/deballasting operations of tankers, discharges of oily bilge-water, tank washing, refinery effluents, municipal waste, discarded lubricant oils, chronic or accidentally petroleum inputs, natural seepages are the most probable sources in these areas.

For the other sites from our study, sources are generally much more pyrolytic than petrogenic . Most Chry/BaA and Phe/An values were under 1 and 10 respectively and Fl/Py values were above 1. Terrestrial inputs by the rivers (Rhone, Ebro) and important atmospheric inputs in relation to industrial activities, steel and iron industries, refineries, cement industry, petroleum unloading, heavy traffic of cargo liners, urban emissions may account for these sources. This is demonstrated or confirmed (Piccardo, 2001, Mille et al., 2007) for the emissions from refineries in Nador, Frontignan, Bejaia, Porto torres, in the complex Rhone-Fos/mer/Marseille stations and around the wreck "Haven" after general pollution from its cargo combustion. For low contaminated areas (Medes, Corsica) inputs after atmospheric transportation may be involved as the source of contamination.

Starting from the frequency distributions of the data, once a particular Johnson curve has been fitted, the normal integral can be used to compute the expected percentage points under the respective curve. In other words, from the p.d.f., specific for each contaminant as shown in Figure. 5, we can evaluate the probability of exceeding a given concentration value or, as a counterpart, the concentration value corresponding to a probability level, fixed a priori. These results are obtained by using the command Johnson Fit() of the R Program and the related functions pJohnson and qJohnson respectively.

Table 2 summarises theoretical variation ranges for each $\mathrm{PAH}$ species and can be considered as a Reference System valid for the Western Mediterranean coasts. Figure 6 
shows an example of graphical representation of the distributions related to some PAH species of interest. These curves represent a diagrammatic version of the Reference System yet presented in the above table. Single experimental observations can be now judged by comparison in terms of low or high accumulation, with regard to their location relative to the lowest or to the highest values, within the full value range identified by the cumulative probability curves.

We have also taken into consideration two important physiological parameters characterising the mussels exposed to PAHs contamination: the \% content of lipids and the Condition Index (C.I., Andral et al. 2004 ). The analysis of the data does not prove the hypothesis of a possible effect on the PAHs accumulation rate, as it results well evident in the fFigure 7, where the interrelationships among these parameters are tested by means of the linear regression. Although the data points are not related to single measurements, but represent average values (medians), referred to geographically homogeneous groups of sampling stations, there are no doubts about the very low or null significance of the correlation coefficient, that is to say that PAHs contamination levels do not seem to be affected by some particular physiological status concerning the mussels. Scarce correspondence between lipid and Total PAH contents in the mussel tissues can be also highlighted analysing the Figure 8, where the median values related to each of the regional coastal reaches are located on the general cumulative probability curves(1). There are no evidence for an agreement of a some type in the two sequences of the coastal areas along the respective probability curves. The rich data-base produced during the Mytilos project campaigns, allows to try a first classification of the contamination levels in the Western Mediterranean sea. In fact, the calculation procedures adopted allow to compute the concentration values of PAHs corresponding to each percentage point of the related distribution. It is possible to identify three contamination levels in the Western Mediterranean basin, by considering three classes: Low $<22.6 \mu \mathrm{g} / \mathrm{Kg} \mathrm{D.W}$. $\leq$ Medium $<35.3 \mu \mathrm{g} / \mathrm{Kg} \mathrm{D.W} . \leq$ High where the chosen concentrations are those defined respectively by the Thirty-third and Sixty-sixth percentile of the comprehensive distribution. In such a way, with a standard period of exposure of 12 weeks and depending on the relative location of the corresponding average values (medians) along the general cumulative curve (see Figure 8), it derives that: a) sampling stations of Corse and Morocco-Algeria coasts are characterised by a low accumulation rate of PAHs in the mussel tissues, b) Sardinia and Italian coasts present on the contrary high levels of accumulation and c) the remaining coastal areas belong to the medium class. At any effect, the proposed criterion reflects the actual variation range of the experimental data and, at least for the moment, it excludes any implication of ecotoxicological nature, with reference to the degree of hazard and possible harmful consequences on the biological communities.

\section{Acknowledgments}

We thank C Tomasino, C. Blottiere, E. Calabretta, C. Codina, P Giordano, V. Perini, F. Oteri, R. Piermarini, M Elbour, A Benrha, A moukrim, S Messaoud, S Boukortte, P Boissery, E Emery, F Lagarde, C Ravel, , G Hervé \& $H$ Thebault for technical and scientific assistance. This reserach was supported by EEC (Interreg /medoccllIC/MYTILOS). INRH (Morocco), ISMAL(Algeria) and INSTM(Tunisia) were supported by UNEP MEDPOL.

$\left({ }^{1}\right)$ Due to the strong non-normality conditions of the sample original distributions related to single regional data-sets, instead of the Group Means and Standard Deviations, the more robust parameters: Medians and Median Absolute Deviations (MDA) have been taken into consideration. 


\section{References}

Andral, B., Stanisiere, JY., Sauzade, D., Damier, E., Thebault, H., Galgani, F., Boissery, P. 2004. Monitoring chemical contamination levels in the Mediterranean based on the use of mussel caging Mar. Poll. Bull. 49, 704-712.

Baumard, P., Budzinski, H., Garrigues, P. , 1998. Concentrations of PAHs (Polycyclic Aromatic Hydrocarbons) in various marine organisms in relation to those in sediments and to trophic level, Mar Poll Bull, 36 , 951-960.

Baumard, P., Budzinski, H., Garrigues, P. , Narbonne, JF., Burgeot T., Michel , X., Bellocq, M., 1999. Polycyclic aromatic hydrocarbon (PAH) burden of mussels (Mytilus sp.) in different marine environments in relation with sediment $\mathrm{PAH}$ contamination, and bioavailability. Marine Environmental Research, 47: 415-439.

Benlahcen, K.T., Chaoui, A., Budzinski, H., Bellocq, J., Garrigues, P., 1997. Distribution and sources of polycyclic aromatic hydrocarbons in some Mediterranean coastal sediments. Mar. Pollut. Bull. 34, 298-305.

Berthou, F., Balouet, G., Bodennec, G. And Marchand M. 1987. The occurrence of hydrocarbons and histopathological abnormalities in oysters for seven years following the wreck of the Amoca Cadiz in Brittany . Marine Enviromental Research, 23: 103-133.

Bouloubassi, I., Mejanelle, L., Pete, R., Fillaux, J., Lorre, A., Point, V., 2006. PAH transport by sinking particles in the open mediterranean Sea: A 1 year sediment trap study. Marine Pollution Bulletin, 52,560-571.

Boehm, D., Page, D., Brown, S., Neff, J., Bence, E., 2005. Comparison of mussels and semi-permeable membrane devices as intertidal monitors of polycyclic aromatic hydrocarbons at oil spill sites Mar. Poll. Bull., 50, 740-750.

Box, A., Sureda, A., Galgani, F., Ponsa, S., Deudero, S., 2007. Assessment of environmental pollution at Balearic Islands using the antioxidant enzyme defences as biomarkers in caged Mytilus galloprovincialis. Comp. Bioch.Physiol. Comparative Biochemistry \& Physiology, Part C 146, 531-539.

Burgeot, T., Bocquene, G., LeDean, P., Truquet, P., Galgani, F, 1993. Measurements in Mullus barbatus in french mediterranean coasts. Sci.Tot Env.,142, 213-220.

Burgeot, T., Bocquene, G., Porte, C., Dimeet, J., Santarella, R., Garcia de la parra, L., PhfolLeszkowicz, A., Raoux, C., Galgani, F, 1995. Bioindicators of pollutant exposure in the northwestern part of the Mediterranean Sea. Mar. Ecol. Progr. Ser. 131 , 125-141.

Burgeot, T., Vincent F., Bocquene, G., His, E., Quiniou , F. Galgani, F., 2001. Monitoring biologcal effects of pollutants : In: Biomarkers in marine organisms; a practical approach. Edited by P. Garrigues H. Barth, C.H. Walker and J.F. Narbonne. Eds. Elsevier.242 pp

Capuzzo, J.M., Farrigton, J.W., Rantamaki, P., Offord, C.H., Lancaster, B.A., Leavitt, D.F., Jia, X., 1989. The relationship between lipid composition and seasonal differences in the distribution of PCBs in Mytilus edulis. Mar. Environ. Res. 28, 259-264.

Celico, F., Esposito, L., Mancuso, M., 2001. Hydrodynamic and hydrochemical complexity of Naples urban area: some interpretation. Geol. Tecn. Ambientale, 2, 35-54. 
Claisse, D., 1989. Chemicals contamination of French coast: the result of a ten year mussel watch. Mar. Pollut. Bull. 20, 523-528.

De Maagd, P.G.-J. \& Vethaak, A.D. 1998. Biotransformation of PAHs and their carcinogenic effects in fish IN: Nelson, A. (ed.). Handbook of Environmental Chemistry. Vol. Chapter 15. p. 265-309.

De Luca, G., Furesi, A., Leardi, R., Micera, G., Panzanelli, A., Piu, P.C., Sanna, G., 2004. Polycyclic aromatic hydrocarbons assessment in the sediments of the Porto Torres harbor (Northern Sardinia, Italy), Mar.Chem. 86, 15-32

De Luca, G., Furesi, A., Micera, G., Panzanelli, A., Piu, P.C., Pilo, MI., Sanna, G., 2005. Nature, distribution and origin of polycyclic aromatic hydrocarbons (PAHs) in the sediments of Olbia harbor (Northern Sardinia, Italy). Mar. Poll. Bull., 50,1223-1232.

Galgani, F, Bocquene, G., , Truquet, P., Burgeot, T., Chiffoleau, JF., Claisse, D., 1992. Monitoring of pollutant biochemical effects on marine organisms of the french coasts. Oceanologica Acta Vol 15, 4 : 355-364.

Galgani, F., Chiffoleau, JF., LeGall, Y., Pichot , Y. , Andral, B., Martin, Y., 2005. Deep sea caging of the mussel mytilus galloprovincialis. Chemistry and ecology, 21(2), 133-141

Geffard, O., Budzinski, H. and His, E. 2002. The effects of elutriates from PAH and heavy metal polluted sediments on Crasostrea gigas (Thunberg) embryogenesis, larval growth and bioaccumulation by the larvae of pollutants from sedimentary origin. Ecotoxicology, 11:403416.

Giovanardi, F., Finoia, M. G., Russo, S., Amori, M. and B. Di Lorenzo (2006). Coastal waters monitoring data: frequency distributions of the principal water quality variables. J. Limnol., 65(2): 65-82.

Gunther, A., Davis, J., Hardin, D., Gold, J., Bell, D., Crick, J., Scelfo, G., Sericano, J., Stephenson, M., 1999. Long term bioaccumulation monitoring with transplanted bivalves in the San Francisco estuary. Mar. Poll. Bull., 38(3), 170-181

Goldberg, E.D., 1975. The Mussel Watch. Mar. Pollut. Bull., 6, 111-113.

Hill, I.D., Hill, R., and Holder, R.L. (1976). Fitting Johnson curves by moments. Applied Statistics. AS99.

IARC. 1989. Diesel and Gasoline Engine Exhausts and some Nitroarenes. IARC Monographs on the Evaluation of Carcinogenic Risk of Chemicals to humans, vol. 46. Lyon, France: International Agency for Research of Cancer. 458 pp.

Incardona, J.C., Teraoka, H. and Scholz, N. 2005. Aryl hydrocarbon receptor-independent toxicity of weathered crude oil during fish development. Environmental Health Perspectives, 113 (12): 1755-1762.

Johnson, N.L., (1949). Systems of frequency curves generated by methods of translation. Biometrika 36: 149-176.

Kock W., Kramer, JM., 1994. Active biomonitoring (ABM) by translocation of bivalve mollusks. In: K.J.M. Kramer, Editor, Biomonitoring of Coastal Waters and Estuarines, CRC Press, Florida (1994), pp. 51-84. 
Lipiatou, E., Tolosa, I., Simo, R., Bouloubassi, I., Dachs, J., Marti, S., Sicre, M.A., Bayona, J.M., Grimalt, J.O., Saliot, A., Albaiges, J., 1997. Mass budget and dynamics of polycyclic aromatic hydrocarbons in the Mediterranean Sea. Deep-Sea Research, 44, 781-799.

Martínez-Gómez, C., Benedicto, J., Campillo, J.A. . and Moore, M.N. 2008. Application and evaluation of the neutral red retention (NRR) assay for lysosomal stability in mussel populations along the Iberian Mediterranean coast. Journal of Environmental Monitoring. 10: $490-499$

Michel, P., 1983. Dosage global des hydrocarbures aromatiques dans les organismes marins par CLHP-fluorescence. In: Aminot, Chaussepied (Ed.), Manuel des analyses chimiques en milieu marin, CNEXO, BNDO/DOCUMENTATION, Brest, France, pp. 337346.

Michel, X., Garrigues, P., Galgani, F., Narbonne, JF., 1994. Modified method for benzo(a)pyrene hydroxylase activity measurements : comparison with EROD activities for marine pollution monitoring. Mar. Env. Res., 38, 257-273.

Mille, G., Asia, L., Guiliano, M., Malleret, L., Doumenq, P., 2007. Hydrocarbons in coastal sediments from the Mediterranean sea (Gulf of Fos area, France) ;Mar Poll Bull, in press

Minier, C., Moore, M., Galgani, F., Claisse, D., 2006. Mxr resistance protein expression in mytilus edulis, Mytilus gallorprovionciallis and Crassostrea gigas from the french coasts. Marine ecology progress series Mar. Ecol. Progress Ser. , vol.22, 143-154.

Norena-Barroso, E., Gold-Bouchot, G., Zapata-Perez, O., Sericano, L., 1999. Polynuclear Aromatic hydrocarbons in american oysters Crassostrea virginica from the Terminos lagoon, Campeche, Mexico. Mar Poll. Bull., 38(8), 637- 645.

Nolan, C., Dahlgaard, H., 1991. Accumulation of metal radiotracers by Mytilus edulis. Mar. Ecol. Prog. Ser. 70, 165-174.

Neff, JM., 2002 . Bioaccumulation in Marine Organisms - Effects of Contaminants from Oil Well Produced Water, Elsevier, Amsterdam , 452 pp.

Parlanti, E., 1990. Utilisation des hydrocarbures comme traceurs d origine de la matiere sédimentaire en milieu marin. Etude du golfe du Lion et du Golfe de Gascogne ( programme Ecomarge). Ph D Thesis, $\mathrm{N}^{\circ}$ 495, University of Bordeaux, France, 122pp

Piccardo, MT., Coradeghini, R., Valerio, F., 2001. Polycyclic Aromatic Hydrocarbon pollution in native and caged mussels. Mar. Poll. Bull. , 42(10), 951-956.

Porte, C., Escartin, E., , Garcia, LM., Sole, M., Albaiges, J., 2000. Xenobiotic metabolising enzymes and antioxidant defences in deep-sea fish: relationship with

contaminant body burden. Mar. Ecol. Prog. Ser., Vol. 192, 259-266

Romeo, M., Hoarau, P., Garello, G., Gnassia-Barelli, M., Girard, JP., 2003. Mussel transplantation and biomarkers as useful tools for assessing water quality in the NW Mediterranean. Environmental Pollution 122 (2003) 369-378

Rantamaki P., 1997. Release ans Retention of selected polycyclic aromatic hydrocarbons ( $\mathrm{PAH}$ ) And their methylated derivatives by the common mussel (Mytilus edulis) in the brackish water of the Baltic sea. Chemosphere, Vol. 35, No. 3, 487-502. 
R Development Core Team (2005). R: A language and environment for statistical computing. $\mathrm{R}$ Foundation for Statistical Computing, Vienna, Austria. ISBN 3-900051-07-0, URL http://www.R-project.org.

Romano, E., Ausili, A., Zharova, N., Magno, MC., Pavoni, M., Gabellini, M., 2004. Marine sediment contamination of an industrial site at Port of Bagnoli, Gulf of Naples, Southern Italy. Mar. Poll. Bull., 49, 487-495.

Soclo, H., 1986. Etude de la distribution des hydrocarbures aromatiques polycycliques dans les sédiments marins récents. Identification des sources. Ph D thesis $N^{\circ} 50$, University of Bordeaux, France, $158 \mathrm{pp}$

Trabelsi, S., Driss, M., 2005. Polycyclic aromatic hydrocarbons in superficial coastal sediments from Bizerte Lagoon, Tunisia. Mar. Pollut. Bull. 50, 344-348.

UNEP/FAO/IOC/IAEA, 1993. Guidelines for monitoring chemical contaminants in the sea using marine organisms. Reference Methods for Marine Pollution Studies No. 6. UNEP, 1993. 28 pages

UNEP/WHO, 1999.: Identification of Priority Pollution Hot Spots and Sensitive Areas in the Mediterranean. MAP Technical Reports Series No.124. UNEP, Athens, 110 pp.

UNEP/RAMOGE, 1999. Manual on the biomarkers recommended for the MED POL biomonitoring programme.UNEP.Athens:1-92.

Varanasi, U., Stein, J.E., Nishimoto, M., Reichert, W.L. and Collier, T.K. 1987. Chemical carcinogenesis in feral fish: Uptake, activation and detoxification of organic xenobiotics. Environmental Health Perspectives 71: 155-170.

Vethaak, A.D., Jol, J.G., Eggens, M.L., Meijboom, A., Rheinallt, T. ap.,Wester, P.W., van de Zande, T., Bergman, A., Dankers, N., Ariese, F.,Baan, R.A., Everts, J.M., Opperhuizen, A., Marquenie, J.M., 1996. Skin and liver diseases induced in flounder (Platichthys flesus) afterlong-term exposure to contaminated sediments in large-scale mesocosms.Environmental Health Perspectives, 104 (11): 1218-1229.

Villeneuve, JP., Carvalho, S., Fowler, SW., Cattini, S., 1999. Levels and trends of PCBs, chlorinated pesticides and petroleum hydrocarbons in mussels from the NW

Mediterranean coast: comparison of concentrations in 1973/1974 and 1988/1989. The Sci. Tot. Env., 237/238, 57-65.

Wheeler, R.E. (1980). Quantile estimators of Johnson curve parameters. Biometrika. 67-3. 725-728 
Table 1 : Summary of PAH levels in 123 stations around the coasts of the NW Basin of the Mediterranean sea

$$
\text { Morocco Algeria Tunisia Italy France Spain }
$$

\begin{tabular}{|c|c|c|c|c|c|c|}
\hline $\mathrm{N}$ & 4 & 8 & 7 & 41 & 23 & 40 \\
\hline$\Sigma \mathrm{PAH}$ & $46.9(20.1)$ & $37.6(10.5)$ & $49(11)$ & $49.9(4)$ & $41.4(7.4)$ & $45.4 .4(7.5)$ \\
\hline Max & 75.8 & 72.5 & 69.7 & 80.4 & 105.5 & 99.9 \\
\hline Min & 29.8 & 25 & 34.2 & 25.6 & 21.9 & 29.8 \\
\hline
\end{tabular}

Table 2: Western Mediterranean sea: Polycyclic Aromatic Hydrocarbons accumulation in Mytilus galloprovincialis

Lower and upper boundary values, corresponding to significant percentiles of the area under the curve of the related p.d.f.

\begin{tabular}{|c|c|c|c|c|c|c|c|c|c|c|}
\hline & $\begin{array}{l}\text { Sampl } \\
\text { e size }\end{array}$ & 0.01 & 0.05 & 0.1 & 0.2 & $\begin{array}{c}0.5 \\
\text { (media } \\
\text { value) }\end{array}$ & 0.8 & 0.9 & 0.95 & 0.99 \\
\hline Condition Index & 122 & 0.056 & 0.059 & 0.063 & 0.070 & 0.099 & 0.144 & 0.166 & 0.180 & 0.195 \\
\hline Lipids (\% content) & 122 & 1.5 & 2.7 & 3.3 & 4.1 & 5.7 & 7.9 & 9.5 & 11.1 & 14.9 \\
\hline Total PAHs $(\mu \mathrm{g} / \mathrm{Kg}$ D.W.) & 122 & 0.5 & 8.2 & 12.5 & 17.6 & 28.4 & 43.2 & 53.8 & 64.8 & 93.0 \\
\hline Naphthalene & 96 & 0.24 & 1.43 & 2.49 & 4.32 & 10.01 & 18.09 & 22.37 & 25.48 & 29.86 \\
\hline Acenaphtene & 82 & 1.07 & 1.11 & 1.17 & 1.33 & 2.41 & 6.49 & 10.38 & 13.77 & 18.20 \\
\hline Fluorene & 117 & 1.44 & 2.06 & 2.51 & 3.18 & 4.98 & 7.53 & 9.17 & 10.65 & 13.61 \\
\hline Phenanthrene & 122 & 0.16 & 1.89 & 2.58 & 3.28 & 4.44 & 5.75 & 6.65 & 7.59 & 10.05 \\
\hline Anthracene & 25 & 0.65 & 1.06 & 1.23 & 1.44 & 1.93 & 2.79 & 3.52 & 4.36 & 6.85 \\
\hline Fluoranthene & 104 & 0.03 & 1.05 & 1.28 & 1.45 & 1.80 & 2.99 & 4.72 & 7.57 & 21.28 \\
\hline Pyrene & 86 & 0.17 & 1.06 & 1.23 & 1.33 & 1.57 & 2.64 & 4.53 & 8.07 & 28.57 \\
\hline Benzo(a) anthracene & 23 & 0.10 & 0.98 & 1.25 & 1.42 & 1.69 & 2.68 & 4.41 & 7.58 & 25.62 \\
\hline Chrysene & 54 & 0.68 & 1.07 & 1.23 & 1.42 & 2.02 & 3.50 & 5.08 & 7.16 & 14.54 \\
\hline Benzo (b) fluoranthene & 24 & 0.96 & 1.02 & 1.08 & 1.23 & 1.95 & 3.88 & 5.42 & 6.76 & 8.77 \\
\hline Benzo (k) fluoranthene & 43 & 1.09 & 1.28 & 1.41 & 1.59 & 2.06 & 2.72 & 3.18 & 3.63 & 4.68 \\
\hline Benzo (a) pyrene & 89 & 1.13 & 1.19 & 1.26 & 1.40 & 2.09 & 4.05 & 5.88 & 7.78 & 11.46 \\
\hline
\end{tabular}




\section{Figures}

Figure 1: localisation of stations (123) and levels of PAH ( $\Sigma$ PAH) in mussels caged along the NW basin of the mediterranean sea.

Figure 2 : Individuals PAH levels in mussels caged along the NW basin of the mediterranean sea.

Figure 3 : Cross interpretation of molecular ratios Fluoanthene/Pyrene (Fl/Pyr), Phenanthene /Anthracene (Phe/An) and Chrysene / benzo -a - Anthracene (Chry/ BaA) in mussels from 123 stations from the North western basin of the Mediterranean sea

Figure 4: Western Mediterranean sea: Polycyclic Aromatic Hydrocarbons accumulation in Mytilus galloprovincialis. The Johnson scheme of frequency curves classification, depending on moments $\beta 1$ and $\beta 2$.

Figure . 5. Accumulation levels in M. galloprovincialis, for some $\mathrm{PAH}$ species of interest in Western Mediterranean basin. Frequency distributions and related Probability Density Functions.

Figure 6: Western Mediterranean sea: Polycyclic Aromatic Hydrocarbons accumulation in Mytilus galloprovincialis. Cumulative probability distribution functions.

Figure 7 Regression between two physiological parameters and the corresponding Total PAHs accumulation in the mussel tissues. Plotted points represent group medians related to homogeneous coastal areas.

Figure 8: Western Mediterranean sea: \% content of lipids $(\Delta)$ and Total PAHs $(\diamond)$ accumulation in Mytilus galloprovincialis. - Relative location of the median values per geographical areas, with respect to the general cumulative distribution curves. (Note: error bars $=+$ MDA) 
Figure 1

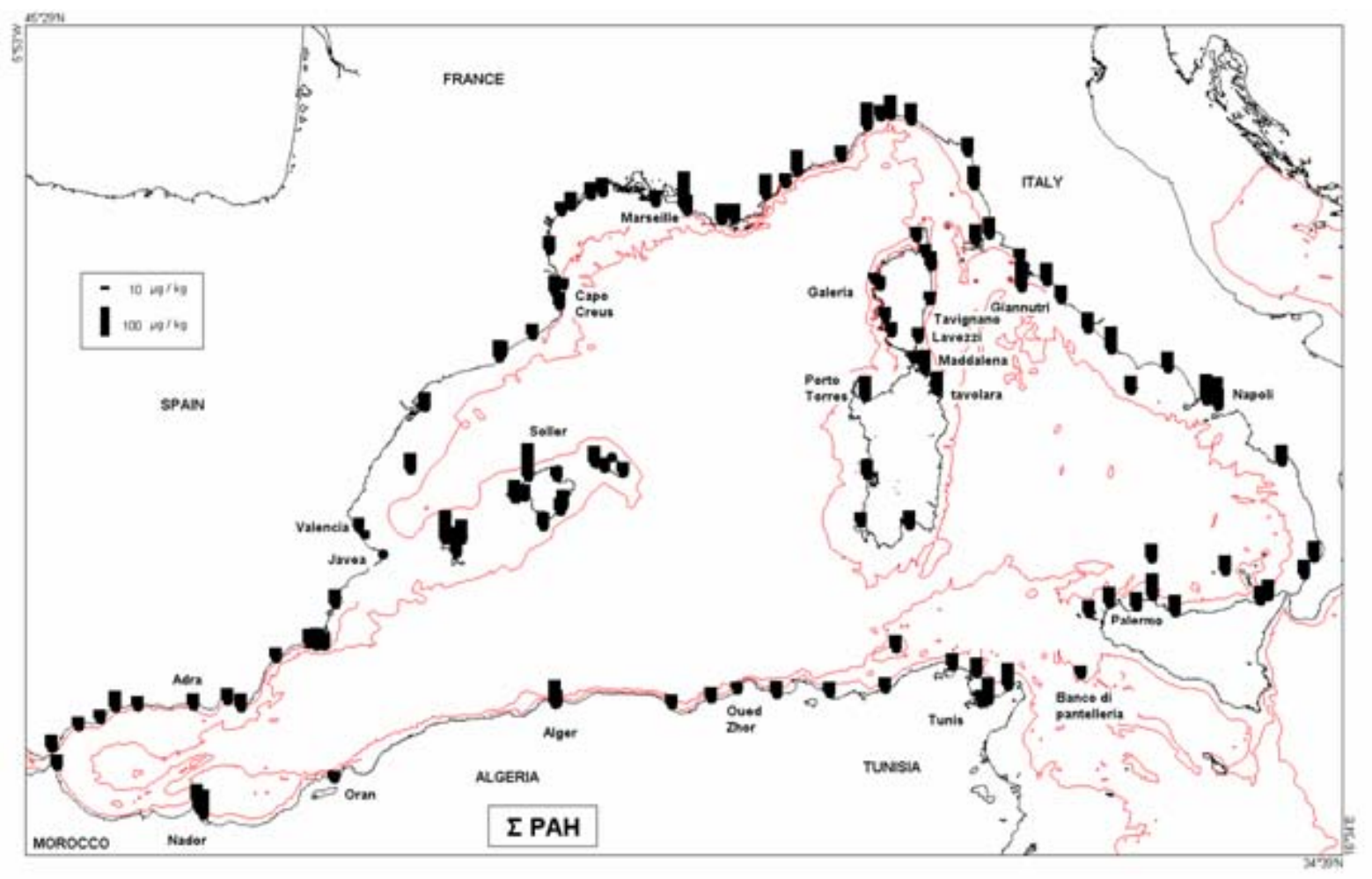


Figure 2
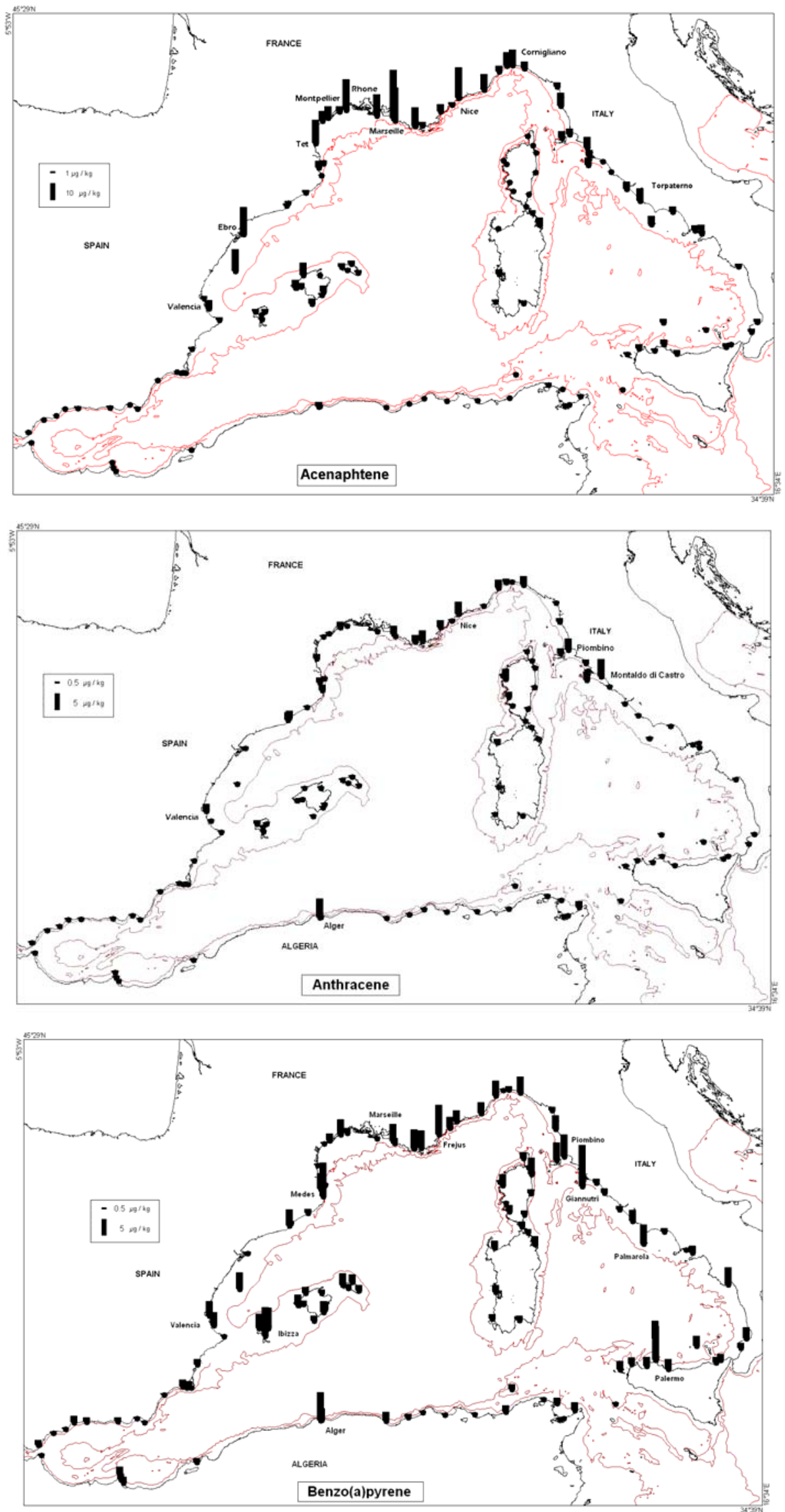

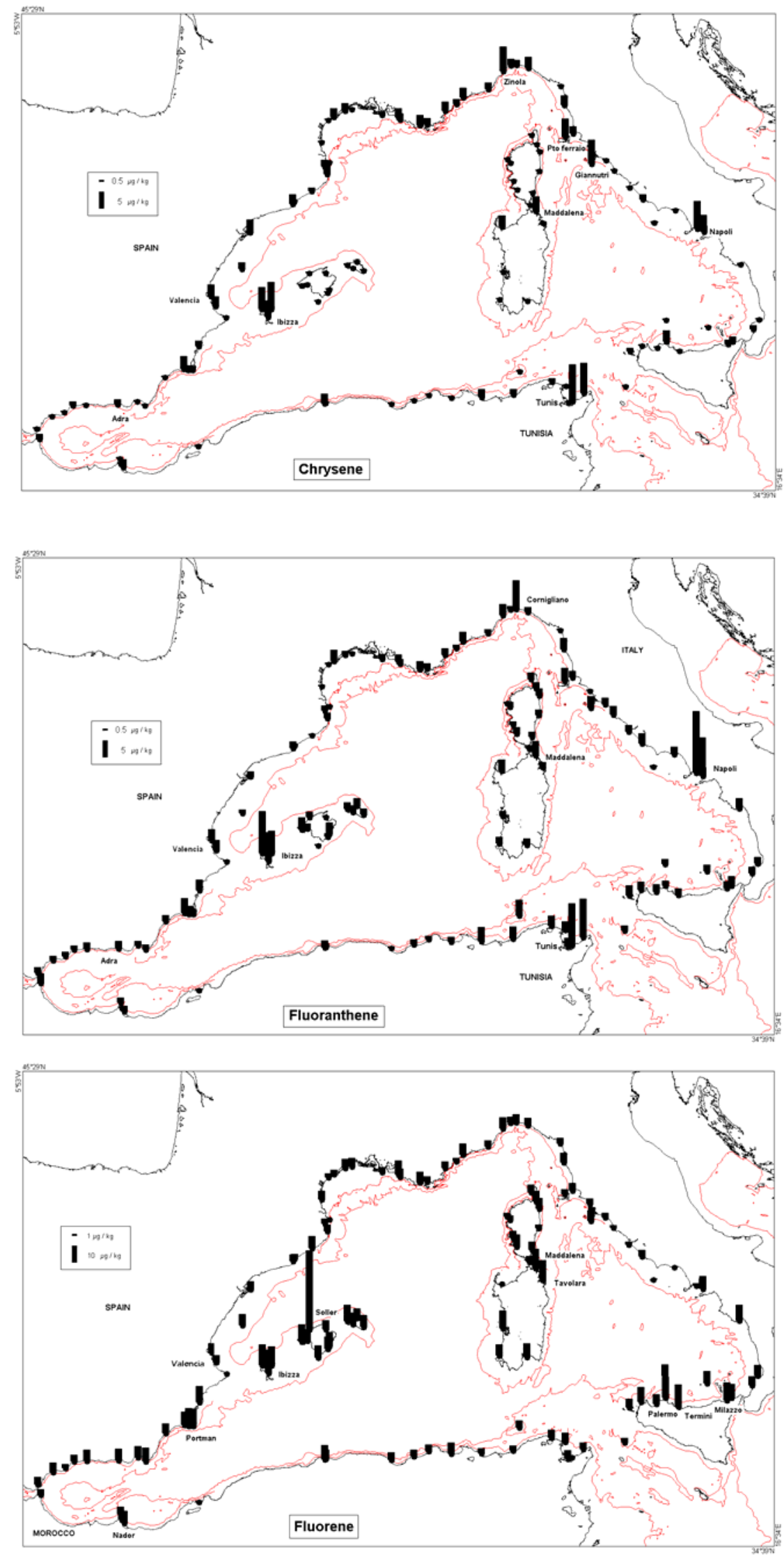

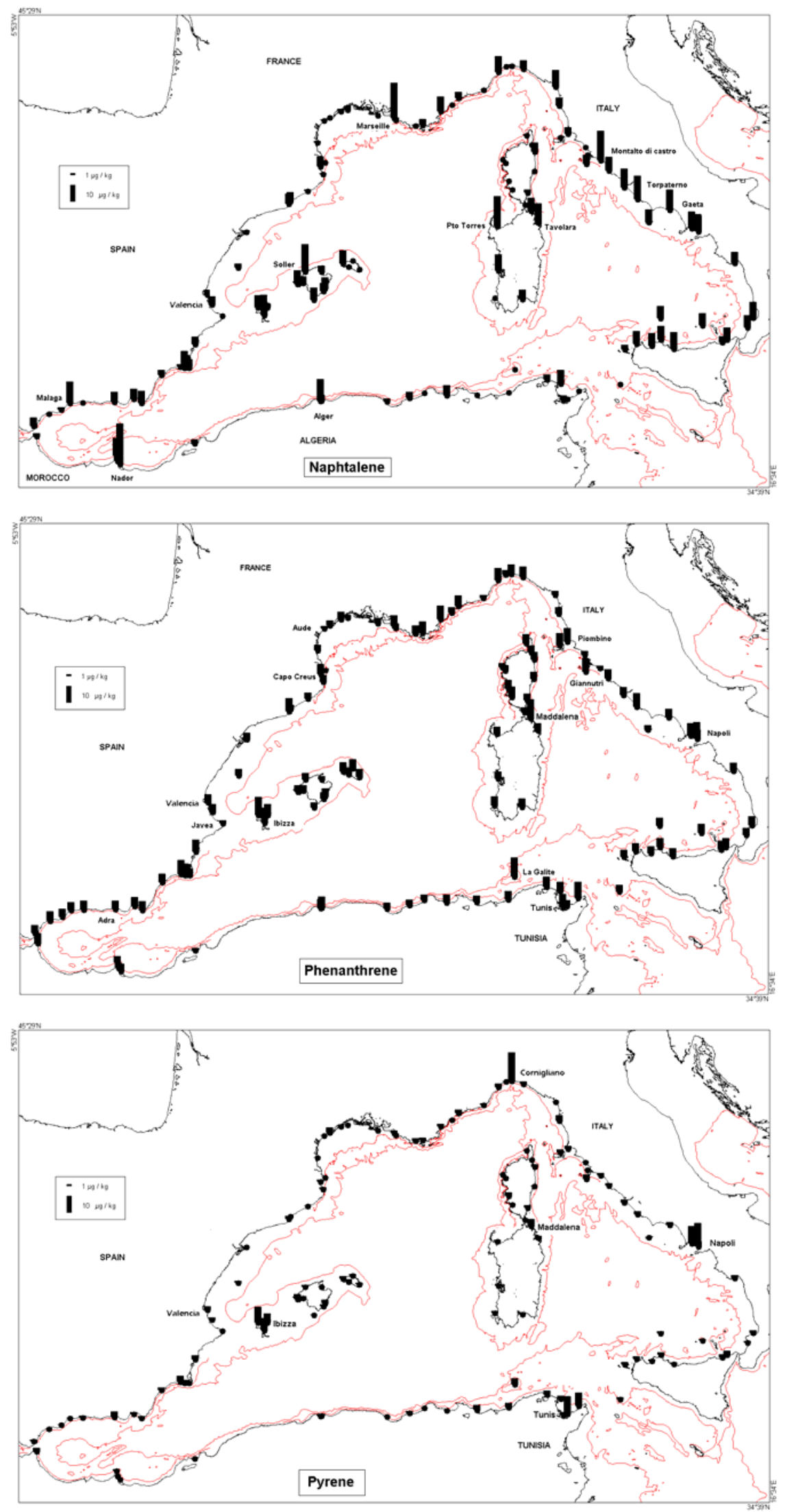
Figure 3
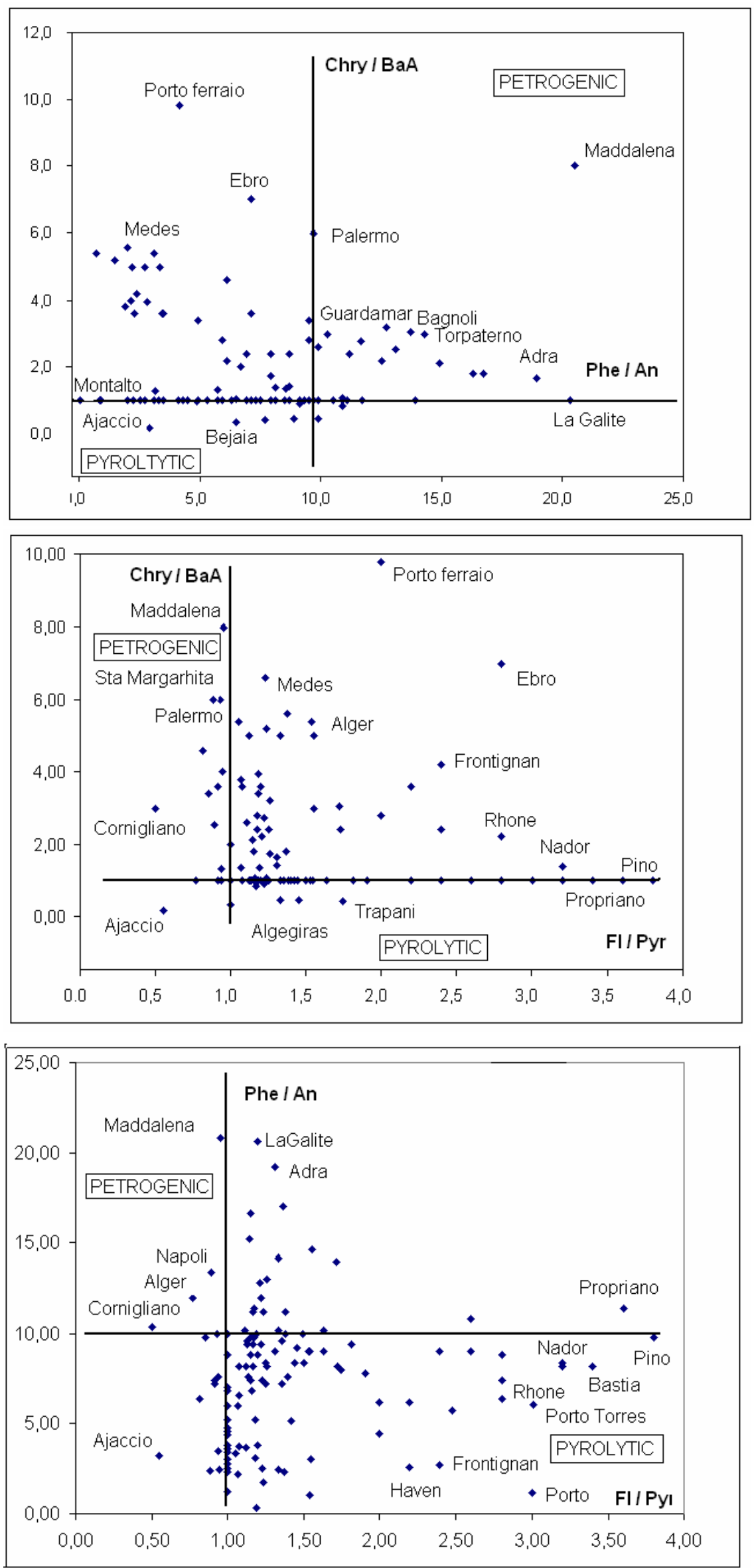
Figure 4
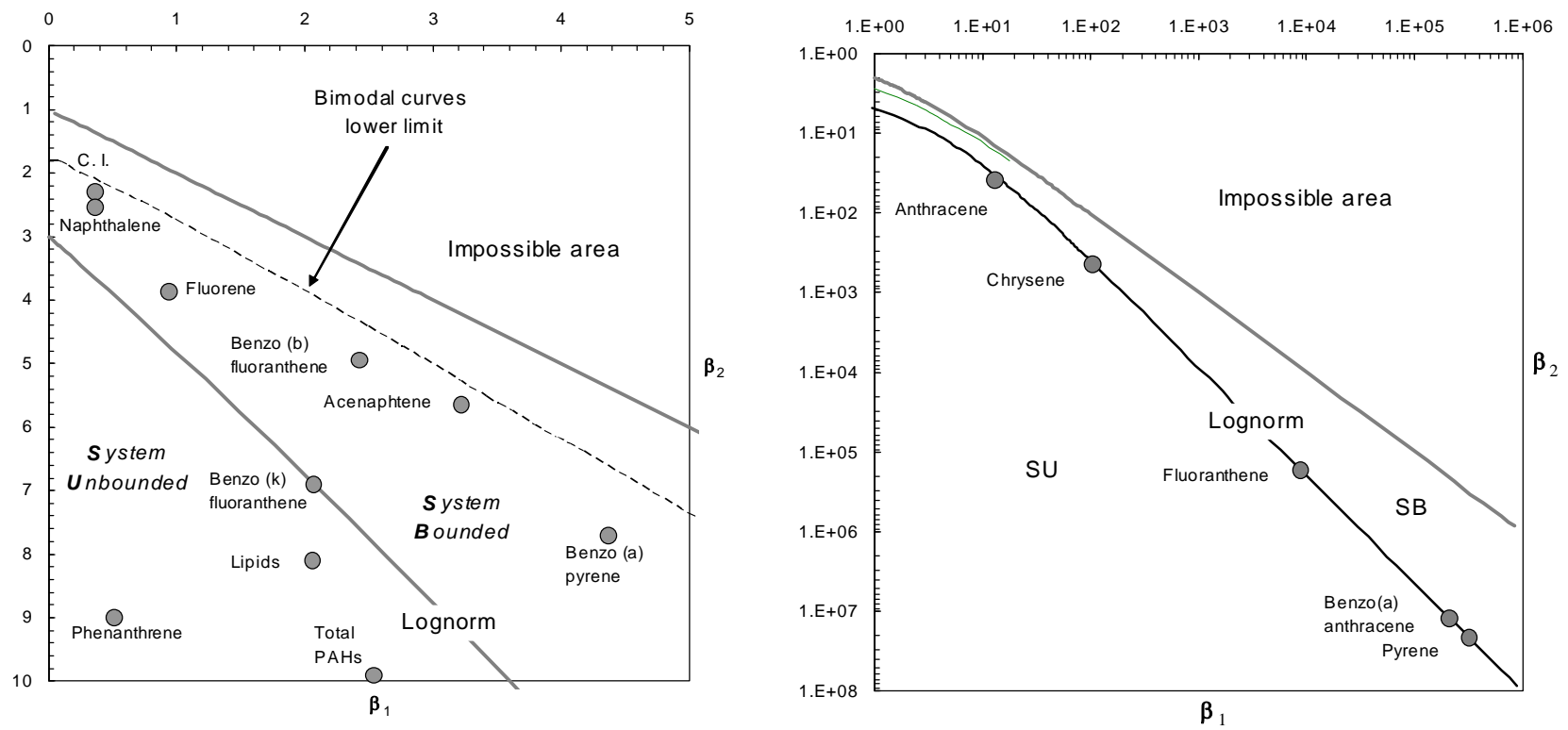

Figure 5

Polycyclic Aromatic Hydrocarb.

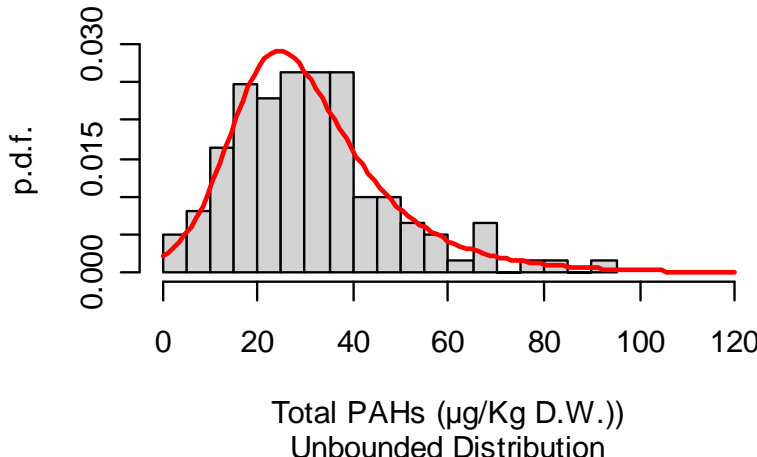

\section{Benzo(k)fluoranthene}
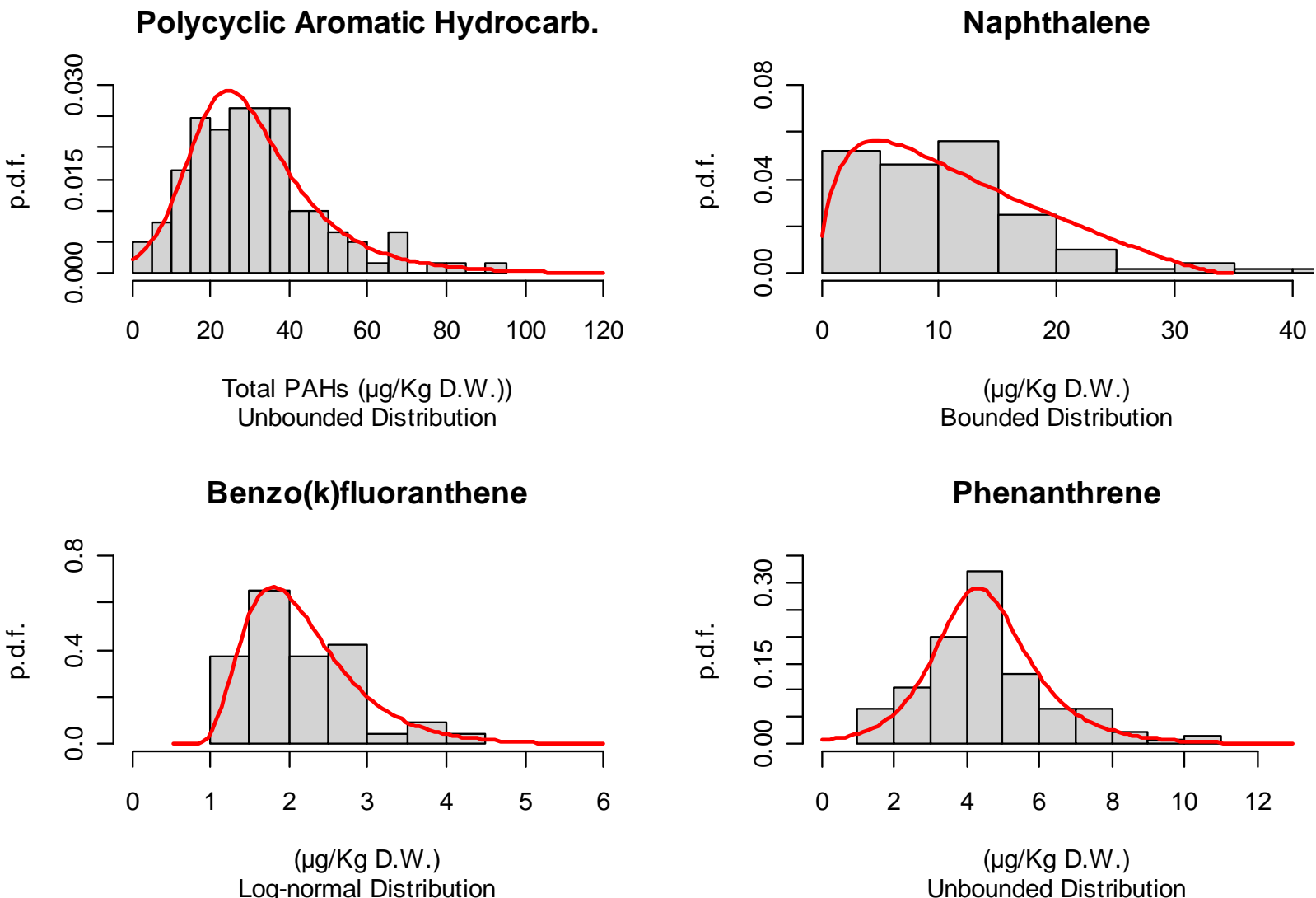

\section{Phenanthrene}

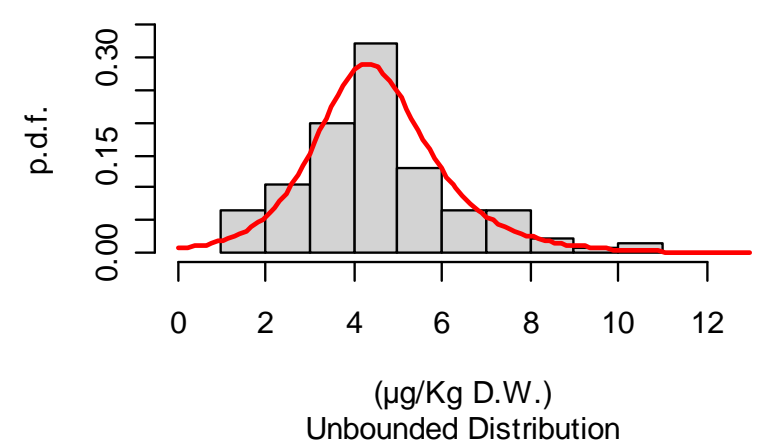


Fig. 6.

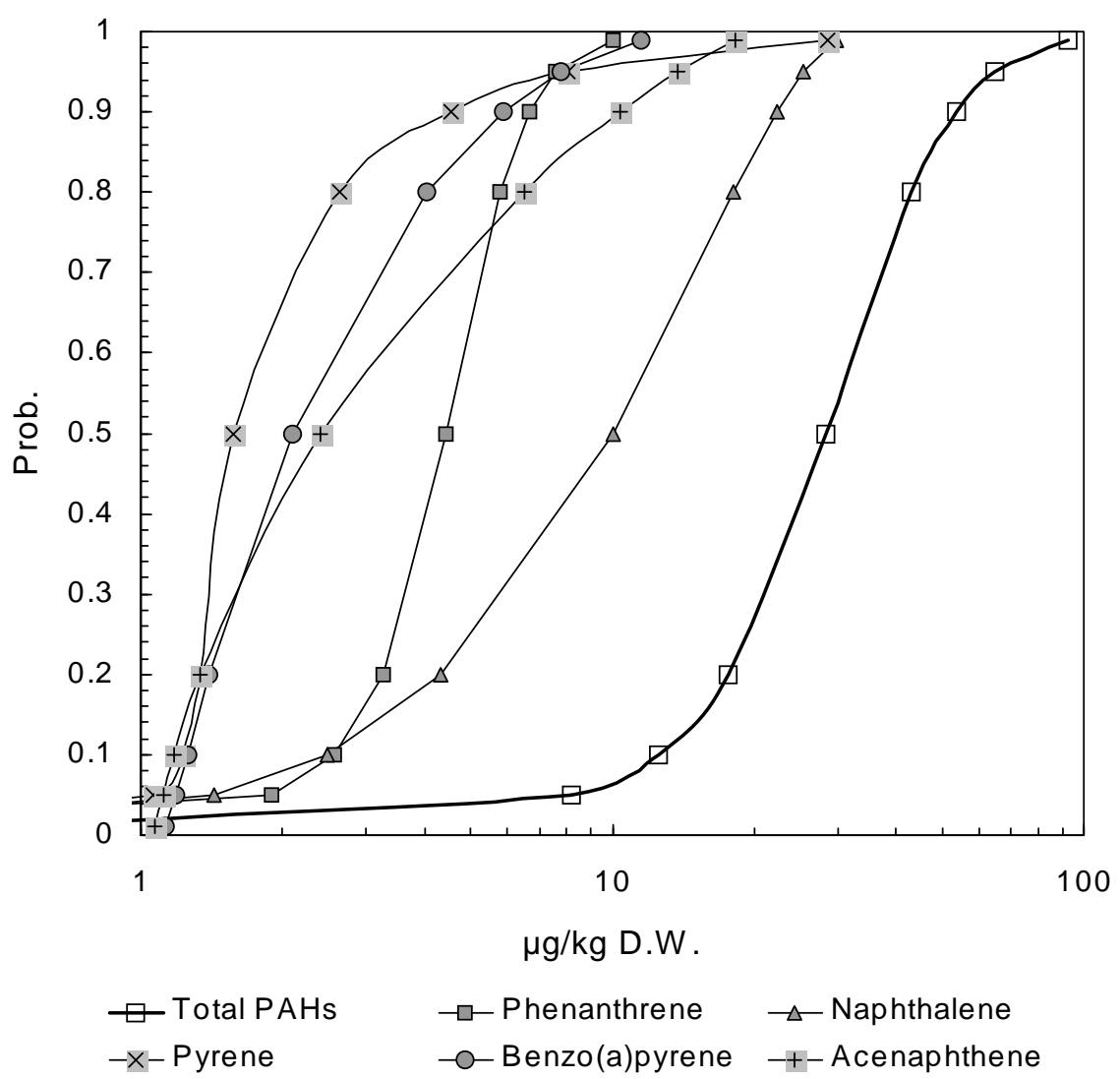


Figure . 7.

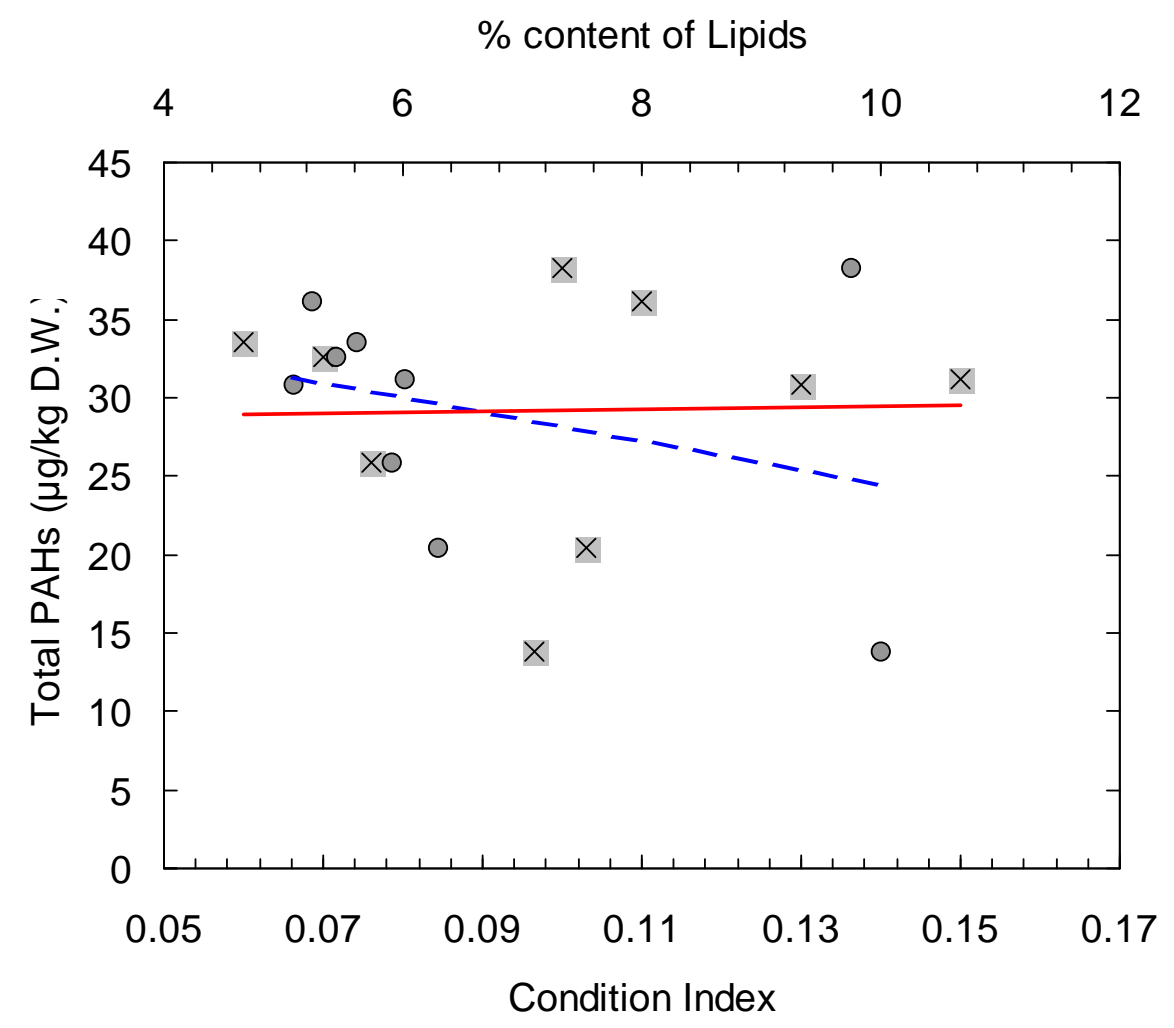

$x \quad$ C.I. $\bigcirc$ Lipids -- Reg. line vs Lipids - Reg. line vs C.I.

Fig. 8 :

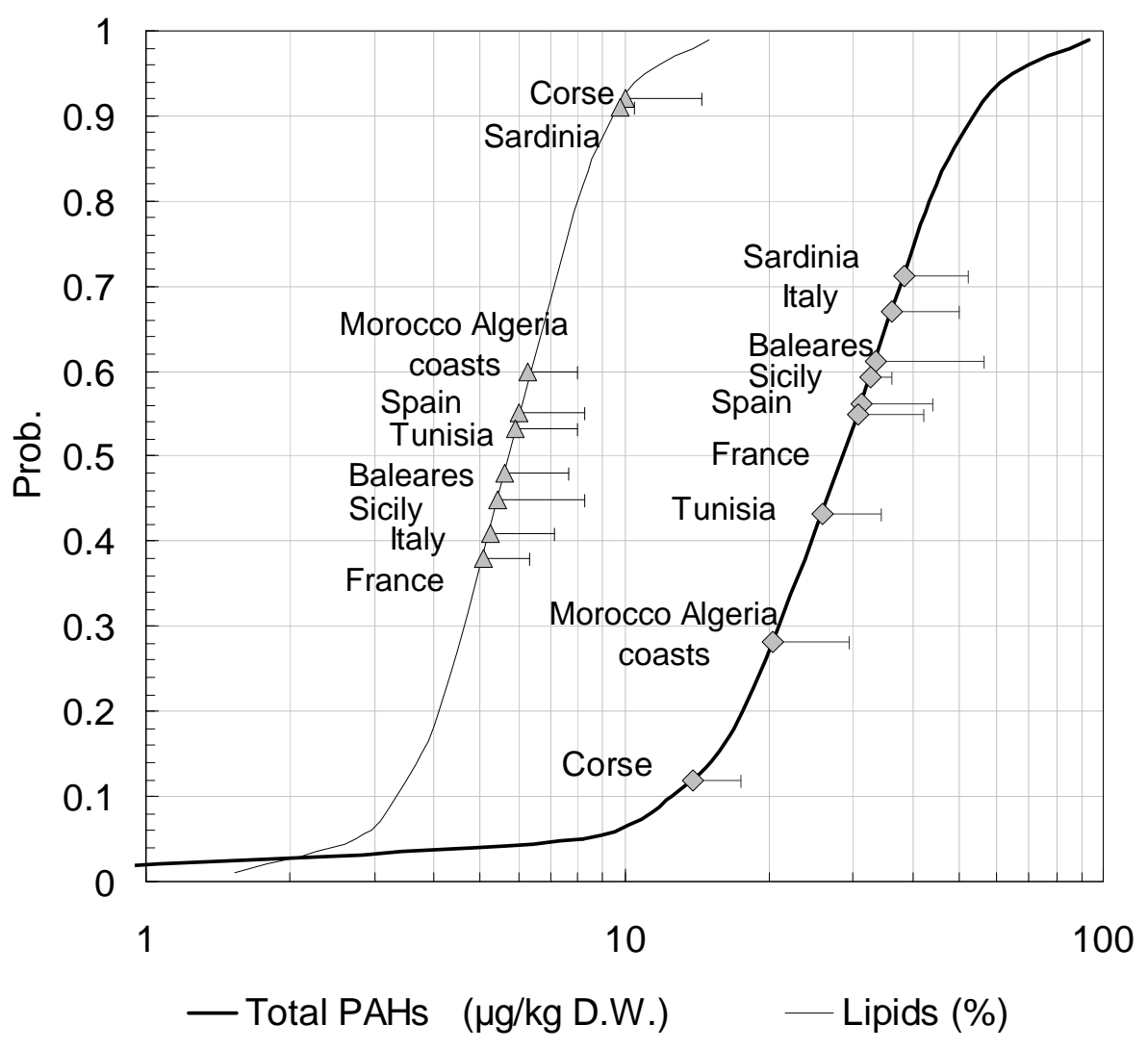

